RESEARCH ETHICS

\title{
The reform of UK research ethics committees: throwing the baby out with the bath water?
}

\author{
S Kerrison, A M Pollock
}

J Med Ethics 2005;31:487-489. doi: 10.1136/jme.2004.010546

On 1 May 2004 research ethics committees became legally accountable to a new government body, the United Kingdom Ethics Committee Authority. This marks the end of the self regulation of research ethics. This paper describes how this change in research ethics committee status has come about and explores the implications for research subjects, researchers, institutions, and for regulation of research.

See end of article for authors' affiliations

Correspondence to

S Kerrison,

Susan.Kerrison@

uclh.org

Received

10 September 2004

Accepted for publication

21 September 2004 published a statement recommending that all human research subjects should under go ethical review. ${ }^{1}$ The College's statement foreshadowed the 1975 World Medical Association's amendment to the Declaration of Helsinki which advocated the establishment of research ethics committees. ${ }^{2}$ Although endorsed by the government, the Department of Health took little interest in the activities of such committees until 1991, when limited guidance was issued about their constitution and operation. ${ }^{3}{ }^{4}$

At that time there was a requirement for each health authority to have at least one research ethics committee. Some committees were district committees but where hospitals had large research portfolios, committees were closely associated with individual institutions, drawing their membership from the consultant body and reviewing research proposals for studies on patients in that hospital. Nevertheless, committees, whether institutional or area based, remained fiercely protective of their independence from hospitals or medical schools and government. ${ }^{5}$

\section{SELF REGULATION TO GOVERNMENT CONTROL - THE NEW ARRANGEMENTS FOR RESEARCH ETHICS COMMITTEES}

The era of self regulation ended in May 2004. Now any research ethics committee considering clinical trials which fall under the European Union clinical trials directive must be constituted and operate under directive rules. ${ }^{6}$ Although clinical trials make up only a minority of medical research studies, ${ }^{7}$ rather than introduce a separate system, the government has taken the opportunity for a root and branch reform.

Under the new regulations, ${ }^{8}$ the links between research ethics committees and research institutions have been broken. Committees are accredited and must operate according to rules formulated by the new UK Ethics Committee n 1964, the Royal College of Physicians
Authority (UKECA). Still acting in a voluntary capacity, ethics committee members now come under the control of this authority, in the sense that the UKECA controls the appointments and procedural rules for the operation of the committees. But the new Authority comprises solely of the secretaries of state for health for the countries in the UK with no formal connections with either professional bodies such as the royal colleges or the General Medical Council. Similarly, although public involvement is considered a high priority for all aspects of health care, no legal requirements have been placed on the Authority to consult the public in any aspects of its decision making. As the new Authority will be controlled directly by the government, these arrangements are at odds with the current trend for the state to manage controversial activity at arms length through the introduction of regulatory agencies such as the Commission for Health Audit and Inspection (CHAI). The new Authority is "independent" of the profession but certainly not independent of government.

\section{STRENGTHS AND WEAKNESSES OF THE OLD RESEARCH ETHICS COMMITTEE SYSTEM}

As a regulatory design, self regulation has a number of recognised strengths ${ }^{9}$-low costs, ability to harness the internal capacities of professional research communities, avoidance of interdisciplinary misunderstanding in interpretation of rules, and sound professional assessment of risks. These strengths were evident in the four research ethics committee which were administered by the University College London Hospitals (UCLH) NHS Trust. Members were not paid but undertook their duties voluntarily for the benefit of their profession or their institution. The only costs were the wages of the committee administrator. Moreover, committees could also harness expert advice from within the profession at little or no cost. Local committees had knowledge of how best to promote research ethics in a local research community. Some committees took the view that that the prime responsibility for the ethical conduct of the study remained with investigator. They did not approve or reject projects but gave investigators "advice". That is to say, in line with current good practice in risk management, ${ }^{10}$ the ultimate responsibility for the control of research risks lay with those who created them-the researchers, not the committee. But investigators known to cut corners might have found that their proposals received special attention. Very few proposals were rejected and researchers would be educated 
about the latest ethics requirements by often lengthy negotiation with the committee. Investigators could sound the committee out in advance and hence incorporate ethical requirement in their research design. In a close coupled system like this, there is less risk of misunderstanding between the committees who make rules and investigators who are expected to follow them. Such misinterpretations beset systems where rule makers become divorced from those expected to comply. ${ }^{11}{ }^{12}$ A further strength was that the committee could operate efficiently by issuing guidance about the types of study that it was essential for the committee to review. Chairs could also use their discretion to ensure that only studies they considered to be of high risk were reviewed by full committee.

However, these strengths were accompanied by considerable weaknesses, not least the absence of resources to monitor adherence and explicit sanctions to enforce good practice-a key requirement of any regulatory system. ${ }^{13}$ Also, with over 100 local committees in the UK and no centralised body with a responsibility for coordination, inconsistency in decision making was inevitable. The latter becomes a considerable problem when an increasing number of studies involve national or international collaboration. ${ }^{14-16}$ Although multicentre research ethics committee, which provide a single review for such studies, were set up in 1997, researchers and industry still found the process too difficult and time consuming, causing costly delays in the process of bringing drugs to market. ${ }^{17}{ }^{18}$ Other criticisms reflected the drawbacks of any self regulatory system-lack of transparency and public accountability. ${ }^{19}$ It is a considerable challenge to make a system based on harnessing the internal control of a profession transparent to the public. Moreover, public trust is required for such an opaque system to be tolerated and scandals such as Alder Hey suggested that the medical profession had become out of step with public opinion.

Further challenges to old arrangements were posed by a changing landscape of medical research. Instead of the traditional interventional study which may pose a risk to a participant's health, studies increasingly involved the use of, or linkage between, tissues or medical records to study genetics - the creation of so called "biobanks". Committees with their roots primarily in the medical profession, equipped to assess health risks to participants, were ill equipped to understand the complex issues of "rights" raised by such projects. Particularly, as these new technologies have become intertwined with policies of actively promoting collaboration between academia and commerce. ${ }^{2021}$

Committees too are expected to understand a raft of new regulatory legislation that provides enhanced legal protection for individual research subjects-for example the Data Protection Act 1998, the Human Tissue Act 2004, as well as the Clinical Trials Regulations 2004. The framing of this legislation means that legal duties are more likely to be placed on organisations, NHS trusts or universities rather than individual doctors or the profession. Such legislation has the effect of requiring organisation to produce policy based on "legal" rules to replace the "old" ethical norms of a profession. ${ }^{22}{ }^{23}$ It is no longer easy to draw a clear dividing line between the responsibilities of institutions and their associated but independent research ethics committees.

\section{DO THE NEW ARRANGEMENTS OFFER GREATER PROTECTION TO RESEARCH SUBJECTS?}

The move from self regulation to direct political control of research ethics is a cause of concern in the ethics community. ${ }^{24}$ In the history of human experimentation, states have had a less than exemplary record-often sweeping away the human rights of research subjects. ${ }^{25}$ Indeed the Nuremberg
Code and the subsequent Declarations of Helsinki were attempts by the judges and the medical profession to develop a framework to protect research subjects against the untoward actions of states. ${ }^{26}$ In the modern context, by taking control of the ethics review, a government intent on seeing biomedical research as an economic driver ${ }^{18}{ }^{21}$ will be in a good position to ensure that such committees do not raise difficult ethical barriers to such research.

But leaving aside these political concerns, will it be more effective in regulating the conduct of researchers? In other sectors, it has been found advantageous to specifically design regulatory systems to enhance the self management capacities of organisations. ${ }^{27}{ }^{28}$ However, the new arrangements for ethics committees seem to impede the self governing capacities of the research community. The work of the committees has intensified as rules meant for the accelerated approval of clinical trials have been imposed on all studies. The committees have lost the discretion to take chairs' action, so all proposals must be reviewed by the full committee. Moreover, the review must be completed within 60 days, only going back to the investigator for information once. The increased pressure raises concerns about the quality of decision making. Unfortunately, the new arrangements may have also weakened the influence of committees over investigators. As committees may receive proposals from many different institutions, they have no local knowledge of the investigator to draw on. The time limits on the committees' decisions means that their capacity to negotiate with the investigator has also been lost. As the link between large institutions and ethics committees has been broken, the committee's capacity for informal influence within a particular institution is weakened. Daunted by the new enlarged national form, investigators in our hospital are now lobbying for "researchers' officers" to complete the form for them. With delegation of the task of applying for ethics review, the disconnection of research ethics from the profession, institution, and investigator will be complete. Ethics approval will become a symbolic activity, which has little to do with the control of the primary risks to research subjects.

\section{REACTIONS TO THE REFORMS}

These changes have been subject of some criticism from within the medical profession ${ }^{17}$ and researchers from other disciplines, caught up in the changes, view the developments with some concern. ${ }^{29}$ An increasing number of universities are setting up research ethics committees to review social science research. The Economic and Social Research Council (ERSC) has recently funded a project to develop a framework for regulating research ethics in the social sciences ${ }^{30}$ and the Department of Health has been consulting social care users. Although such university committees are currently based on self regulation, worried glances are being cast at the developments in medicine.

Will the research ethics in other disciplines ultimately be controlled by government? The reforms are opening up far more fundamental questions. In particular, is the current system for protecting research subjects, resting on committees taking decision in private, outmoded-whether controlled by professions or governments? Modern approaches to regulation emphasise two strategies: regulatory systems which are in harmony with systems of internal control ${ }^{27}$ and as regulation is "government in miniature" , involvement of all stakeholders. ${ }^{31}$ For research ethics, this would mean not only mending and strengthening the links with the institutions which have control over researchers-professional, academic, and healthcare providers but also developing procedures for involving the public in all aspects of decision making about research. 


\section{ACKNOWLEDGEMENT}

The authors thank Colin Scott, LSE, for sharing his thoughts on this subject.

\section{Authors' affiliations}

S Kerrison, A M Pollock, School of Public Policy, University College London Hospitals NHS Trust, London, UK

S Kerrison is Assistant Director of Research and Development, UCH NHS Foundation Trust and Senior research fellow at School of Public Policy UCL, London.

A M Pollock is Director of Research and Development, UCH NHS Foundation Trust and Professor of Health Policy, School of Public Policy, UCL, London.

\section{REFERENCES}

1 Royal College of Physicians of London Committee on the Supervision of the Ethics of Clinical Investigations in Institutions, July 1967.

2 World Medical Assembly Tokyo, Japan, October 1975.

3 Department of Health Local Research Ethics Committee HSG(91)5.

4 Department of Health Standards for local research ethics committees-a framework for ethical review. London: Department of Health, 1994.

5 Royal College of Physicians. Guidelines on the practice of ethics committees in medical research involving human subjects, 3rd edn. London: Royal College of Physicians, 1996.

6 Directive of the European Parliament and of the Council on the approximation of the laws, regulations, and administrative of provision of the member States relating to implementation of good clinical practice in the conduct of clinical trials on medicinal products for human use. 2001/20/EC.

7 The research portfolio of research studies ongoing at UCLH NHS Trusts consists of 200 clinical trials and 1000 other studies.

8 SI 2004 No 1031. The Medicines for Human Use (Clinical Trials) Regulations.

9 Black J. Constitutionalising self regulation. Modern Law Review 1996;24.

10 Health and Safety Executive. Reducing Risks and Protecting People. London: Health and Safety Executive, 2001
11 Black J. Talking about regulation. In: Harris $M$, Partington $M$ eds. Administrative Justice in the 21 st Century. Oxford: Hart, 1999

12 Black J. Using rules effectively. In: Mcrudden C, ed. Regulation and Deregulation. Oxford: Clarendon Press, 1999

13 Baldwin R, Scott C, Hood C. Regulation. Oxford: Oxford University Press, 1998:p1-55, Introduction.

14 Hearnshaw H. Comparison of requirements of research ethics committees in 11 European Countries for a non invasive interventional study. BMJ 2004;328:140-1.

15 Glasziou P, Chalmers I. Ethics review roulette: what can we learn? BMJ 2004:328:121-2.

16 Nichols J. The ethics of research ethics committees. BMJ 2000;320:1217

17 Department of Health Pharmaceutical Industry Competitive Taskforce. DGH: London, 2000. www.adivsorybodies.doh.gov.uk/pict/ (accessed 17 November 2004)

18 Department of Health. Science and Innovation Strategy. London: Department of Health, 2001.

19 Ashcroft R, Pfeffer N. Ethics behind closed doors. Do research ethics committees need secrecy? BMJ 2001;322:1294-6.

20 Harrison A. Getting the right medicines. London: King's Fund, 2003

21 Harrison A, New B. Public interest, private decisions: health-related research in the UK. London: King's Fund, 2002.

22 Kerrison SH, McNally N, Pollock AM. United Kingdom research governance strategy. BMJ 2003:327:553-6.

23 Jacobson PD. Regulating health care: self regulation to self-regulation? $J$ Health Polit Policy Law 2001;26:1165-77.

24 Nicholson R. Another threat to research in the United Kingdom. BM 2004:328:1212-14.

25 Childress J. Nuremberg's legacy: some ethical reflections. Perspect Biol Med 2000;43:347-61

26 Annas G, Grodin M. The Nazi Doctors and the Nuremberg Code: Human Rights in Human Experimentation. Oxford: Oxford University Press, 1992.

27 Ayres I, Braithwaite J. Responsive Regulation: transcending the deregulation debate. Oxford: Oxford University Press, 1992.

28 Power M. The Risk Management of Everything: Rethinking the politics of uncertainty. London: Demos, 2004

29 See Discussion Paper 1 at www.york.ac.uk/res/ref (accessed 17 November 2004).

30 See: Developing a framework for social science research ethics. www.york.ac.uk/res/ref (accessed 12 July 2004).

31 Prosser T. Law and the regulators. Oxford: Clarendon Press, 1997:305.

\section{Call for papers}

The Journal of Medical Ethics is planning to publish a number of thematic issues and invites submissions of original or short papers on the following topics:

Deadline 15 June 2005

Neuroethics

Deadline 15 December 2005

Public Health Ethics

Ethical issues is obstetrics and gynaecology

Multidisciplinary research in medical ethics

\section{Deadline 15 June 2006}

Equity and justice in health care

Ethical issues in oncology and palliative care

Teaching ethics to health care students and professionals

If you would like to discuss a possible submission please e-mail Søren Holm at holms@cardiff.ac.uk with your idea. Prior discussion with the editor is not obligatory.

Please state in your submission letter that you would like the paper considered for a thematic issue. 